\title{
WORLD IMAGE IMPRESSIONS IN "DEVONU LUGOTIT TURK"
}

\author{
Muyassar Ibrohimova
}

Doctoral Student, Uzbek Language, Literature And Folklore Institute, Uzbekistan

\section{ABSTRACT}

The article discusses the importance of the image of the world in Mahmud Kashgari`s "Devonu lug'otit turk" the art of artistic representation.

KEYWORDS: - Devon, "arghuch", “ajun”, “tashhis”, world.

\section{INTRODUCTION}

It is known that the work of the famous linguist and ethnographer Mahmud Kashgari's "Devonu lug'otit turk" is an encyclopedic source that expresses the ancient traditions, lifestyle and attitude of the Turkic peoples to material existence. It contains not only examples of folklore, literary fragments of the XI century, but also the period before that. In these poems, the heroic struggle of the tribal heroes, natural phenomena, the dreams and hopes of the people are vividly expressed. The lyrical passages in Devon contain a number of images such as spring, winter, heart, bow, arrow, wine, hunting, bird, tree. Among them, the image of the world is distinguished by its scale of meaning, metaphorical nature and its art. Our analysis has shown that although the world is given by the word "ajun" from the beginning to the end of Devon ("ajun"-the world, "bu ajun" - this world, "ol ajun" -the other world, the world after death. - M.I.), in poetic passages it has several layers of meaning. That sometimes reveals time, sometimes period, social environment or material world - the content of existence. For example, in the anthem "Alp Er Tonga", the world is interpreted as the cause of all sorrows, unhappiness and separation:

Алп Эр Тона ўлдиму

Эсиз ажун қалдиму.

Ўзлак ўчин алдиму,

Эмди журак жиртилур.

(Unfortunately, did Alpartunga the hero died, did the evil world get separated from him, did the time take revenge on him, now hearts are hurting for him.)

In the poems quoted in Devon, the word ajun is often used interchangeably with the words "ogru, ozlak", that mean time. In the above quartet, too, the word "ozlak" served to deepen the meaning 
CURRENT RESEARCH JOURNAL OF PHILOLOGICAL SCIENCES 2(6): 98-

101, May 2021 DOI: https://doi.org/10.37547/philological-crjps-02-06-20

ISSN 2767-3758

(C)2021 Master Journals

\section{Crossref do) 8 Google}

Accepted25thJune, 2021 \& Published 30thJune, 2021

of the lyrical protagonist's attitude towards the world, further reinforcing the meaning expressed through ajun.

Apparently, Afrosiab - Alp Er Tonga is a legendary hero of the Turkic peoples. The quartet vividly illuminates the transience of the world, taking advantage of the art of "talmeh".

In Devon, many places in the world are characterized by the "arghuch", that is a quality which makes people rush and feel proud. It is noteworthy that we came across the epithet "arghuch ajun" - the proud world - only in "Devonul-lug'otit turk". This proves the uniqueness of the image of the world in the poems used in Devon. In the following verse, it is said that to love this world, to give in to its fleeting desires, is to be deceived by the lies of the devil:

Барди сена жек отру тутуп бал,

Барчин кезибан талу жушға болуп қал.

(Satan met you, gave you honey, and gave you the sweetness of the world. You wore silk clothes with pride. If you don't understand his deception, stay and enjoy yourself).

It is clear that the ideas expressed in the verses are influenced by the principles of Islam, that is, the ideas of the Koran. In particular, the Koran states that the world is a means of misleading people, diverting them from the Creator, and turning them into the devil's tricks: "Eventually, the Satan showed the way of trick beautifully to those who have returned from the right way towards sins"(Muhammad: 25). From this it is clear that some of the poems in "Devon" are in harmony with the spiritual and moral views of the peoples of the East, the teachings of Islam and universal ideas. These ideas can also be expressed in the following poem example:

Кўзум жаши сашруқиб қузу оқар,

Билкиб ажун эмгагин тугал уқар.
(Tears well up in my eyes as I fully understand the challenges of the world.)

This literary passage depicts the sad image of a wise man who fully understands the essence of the world. It is inevitable that a person who has wasted the pleasures of life and the pleasures of the mortal world in vain will not understand the "difficulties". Because he is always busy with those worries. But the lyrical protagonist is a man with a deep nature and a clear mind. He cannot stop his tears even after he has "fully understood" the meaning of life, that is, when he cannot find any meaning in his fleeting desires. Thus, the spiritual world of the lyrical hero in the poetic passage, the glorious image, introduces the reader to himself. The reader feels close to him, spiritually and emotionally.

In another passage, it is stated that man came to this world only to suffer, and the above ideas are developed:

Эмгаксизин турғу жоқ мунда таму,

Эзгулугун кўрмазиб ажун чиқар.

(It is impossible for a person to live in this world without hardship. Without seeing any good, a person dies).

No matter how sweet life is, it will not pass without hardship. Life is so short that a person can pass through this world without seeing any good. Time, opportunity, changes in nature can not interfere with the natural laws of the universe. Only man's "being injured", that is, his death, is inevitable:

Туғун тақи қалмади мангу эран

Ажун куни жулдузи тутчи туғар.

(Describes the time: a born man does not always live. But the sun, the star of the world always shines, never gets hurt).

The lyrical protagonist is a thoughtful man trying 
CURRENT RESEARCH JOURNAL OF PHILOLOGICAL SCIENCES 2(6): 98-

101, May 2021 DOI: https://doi.org/10.37547/philological-crjps-02-06-20

ISSN 2767-3758

(C)2021 Master Journals

\section{Crossref do: 81 Google}

Accepted25thJune, 2021 \& Published 30thJune, 2021

to understand the events of the world, trying to find an answer to the question of why everything is eternal, but human life is temporary. He deeply understands the judgment of destiny, the essence of humanity, the meaning of life. That is, in the lyrical passage there is also an expression of an optimistic spirit that, as life is fleeting, it should be adorned with goodness. In the following poem, the word "ajun" also means time and period:

Ажун тўни кўндузи жэлкин кэчар

Кимки қали сатғаса кўчин кэшар.

(The days and nights of time pass like travelers. He breaks the power of the one he looks down on. This word is used in the Oghuz as a way and a debt).

In poetry, the art of "tashhis" increases the power of thought. That is, night and day are being revived and made to look like tourists. And time is angry - whoever looks bad, his strength will be tested. Life is a long way and a debt. At the end of the road, the opportunity to repay the loan is approaching. It is clear from this that the world is not temporary in man, but man is temporary guest in the world. Eventually, the debt is returned to its owner. There are many such metaphors in Devon.

Ўгру жуги мундағ оқ,

Мунда азин тэндағ оқ.

Этса ажун оғраб оқ,

Тағлар баши кэртилур.

(This is the custom of the age, and there are other destructive reasons for it. If it is shot towards the other world, the heads of the mountains are brought)

In this quartet, images of the world and time are used in parallel, and the modern world is portrayed as the cause of the catastrophes.
Through the art of "tashhis", time is vividly depicted as the enemy of time to the world, shooting at it. As it passes, even the mountains will crumble and disappear.

Ўзлак ариғ кешради,

Жунчиғ жавуз кевради.

Эрдам жема cewради,

Ажун беги чертилур.

(Time has dwindled, the weak, the idiots have intensified. The people of the time have lost their virtue with the death of Afrosiab).

Professor Abdurauf Fitrat combined fourteen quatrains ("Is Alp Er Tona dead?", "the world is waiting for its time", "There is nothing better than a tradition", "the members of the world is has diminished", "They died like wolves," "My heart was pounding," "My wrists were struggling" - M.I) with the name of Afrosiab's lament. The scientist added the quartet with the image of the world to the composition of the lament:

Билга боку жунчиди,

Ажун ати жанчиди.

Жерга тегип сўртўлур

Эрдам эти тинчиди.

(Explaining the state of the time, he says that the condition of the scholars has worsened. The time has bitten and tormented them, and even the flesh of decency and virtue has been corrupted and stinked.

In this passage, the period after Afrosiab's death is condemned as the cause of all evils, while in another place the world is used in the sense of material being, nature:

Жаж кўркина инонма,

Сушлар ўза тажанма.

Эсизлирир анунма, 
CURRENT RESEARCH JOURNAL OF PHILOLOGICAL SCIENCES 2(6): 98-

101, May 2021 DOI: https://doi.org/10.37547/philological-crjps-02-06-20

ISSN 2767-3758

(C)2021 Master Journals

Crossref do: 81 Google

Accepted25thJune, 2021 \& Published 30thJune, 2021

Тилда (н) чиқар эзгу сўз.

(Do not believe in the splendor of spring, its colorful flowers, its beauty, do not hope for good from it, do not rely on water, because those who rely on the sweetness of worldly blessings, the beauty of spring are like those who rely on water.

At this point, believing in the pleasures of the world is like relying on water. It is noteworthy that this tradition has continued in our classical literature as well. Here is what Muhammadrizo Agahi says in one of his translations, as if influenced by the above lyrical passage:

Дахр уйи бунёдким сув узадир, махкам эмас,

Онда кирган ел хавотирдин амон бир дам эмас.

\section{Conclusion}

In general, many poetic passages from Devon, quoting the world and its artistic interpretations, can be cited as examples. Mahmoud Kashgari does not simply interpret the world and the words that come with it. Rather, it uses examples rich in unique findings, poetic imagery, and symbols in the living language of the people. In the passages describing the qualities of the world, we encounter parables and systems of symbolic expression that encourage us to be aware of its actions, while the quartet of time and epochs emphasizes the transience of the world. In the places that surround us, in the sense of the material world, natural phenomena are mainly described.

\section{REFERENCES}

1. Mahmud Kashgari "Devonu lug'otit turk"

2. Fitrat A. Selected Works, Volume IV. Tashkent: Manaviyat, 2006. 120 pages

3. Literary theory. Two roofs. Volume 1 Tashkent: Fan, 1978. - 415 p.
4. Literary theory. Two roofs. Volume 2 Tashkent: Fan, 1979. - 444 p. 